\title{
Elena Franchi*
}

\section{Genealogies and Politics: Phocus on the Road}

DOI 10.1515/klio-2017-0001

Summary: On usually refers to all the figures named „Phocus“ as one and the same Phocus, the alleged eponymous hero of the Phocians, and wonder why he has so many „Doppelgänger“: one or more Homeric heroes, a son of Aecus, a son of Ornytion, and so on. This paper assumes instead that there are many different heroes whose names are Phocus, and wonders to what extent and why they were linked. Indeed the contradictory stories about

Phocus represent an interesting case of the permeability of the heroes' genealogies and of the traditional narratives about them in archaic and classical Greece. A survey of the sources shows that all the figures named

„Phocus“

were more than once linked together to express specific needs. These needs reflect different aims and historical events which are ascribable mainly to the archaic and classical periods. Moreover, they are concerned with Phocis as well as with Corinth, Aegina, Locris, Thebes and Thessaly. By reconstructing wherever possible the chronological context of the different layers and overlaps and by linking them to the several traditions concerning heroes named Phocus, it is possible to construct a map which describes some of the relationships, some geopolitical landscapes and, to a certain extent, even some geopolitical lines working in Central Greece and beyond from the archaic to the Roman period.

Keywords: Phocus, genealogies, Phocians, Corinthian stasis, Aegina, Thessalians

\section{Introduction. Starting an Inquiry from Pausanias' Puzzling Stories}

Born in Aegina or in Corinth, son of Aeacus or of Ornytion, struggling against Homeric heroes but also fighting much later in Locris, and marrying a Theban princess: how many characters named Phocus acted in how many different chronological and geographical contexts?

We usually refer to all the figures named „Phocus“ as one and the same Phocus, the alleged eponymous hero of the Phocians, and wonder why he has so

*Corresponding author: Elena Franchi, Trento, E-Mail: elena.franchi@unitn.it 
many „Doppelgänger“. This paper starts instead from the contention that there are many different heroes whose names are Phocus, and the question therefore becomes: to what extent and why were they linked? And what were the predominant semantizations operating in these links?

In fact, the contradictory stories about Phocus represent an interesting case of the permeability of the heroes' genealogies and of the traditional narratives about them in archaic and classical Greece, as described by Rosalind Thomas and Irad Malkin. ${ }^{1}$ Indeed, we know of a Phocus who is the eponymous hero and archegetes of the Phocians; ${ }^{2}$ one born in Aegina; one born in Corinth; and many others whose different genealogies sometimes intertwine before separating out again, as will become clearer over the course of this paper.

The challenge for the historian is to recognise in this intertwining and separating out of genealogies, in their selective permeability, the reflection of aims and historical events in a narrow sense. The relationships and adventures of a Phocus are narrated in connection with the Phocians, but also the Locrians, Thessalians, Corinthians and Aeginetans. At a closer look, the traditions which witness these reflect as many historical realities, different in time and space, that have generated these same traditions. In other words, in studying the various heroes named Phocus a map of cultural and political relationships of the Phocians in archaic and classical times can be reconstructed.

In fact, a figure named Phocus is attested in poetry, in historiography, in tragedy as well as in iconography. In order to start an inquiry into the tradition about Phocus and his puzzling stories it is necessary, however, to start from one of the latest sources: Pausanias. Pausanias knows two eponymous heroes who are both called Phocus and examines them one after the other.

The first Phocus who, according to Pausanias, arrives in the region called after him (the region „,around Tithorea and Delphi“) is the son of Ornytion and the grandson of Sisyphus, the founder of Corinth. For these reasons, this Phocus is considered a Corinthian (10.1.1). As McInerney observes, this story was also told in Corinth: Pausanias cites this Phocus also in the passage which is dedicated to Corinthian mythology and writes there that in the ancient world it was even assumed that this Phocus was the son of Poseidon, which underlines

1 See e. g. Malkin (2001) esp. the article of Thomas (2001) with further literature.

2 Paus. 10.1.10. An archegetes supposed to be Phocus is worshipped in a heroon which is near the „Phokikon“, the federal meeting place of the Phocians (see Paus. 10.5.1-3; 4, 1; French Vanderpool (1963) 213-225; French (1984) 89-96; McInerney (1997) 193-207; Daverio Rocchi (2011) 22 (= Daverio Rocchi [1999] 16); 29-32 (= Daverio Rocchi [1999] 23-26); 41 (= Daverio Rocchi [1994] 182); 46 (= Daverio Rocchi [1994] 187); 48 ff (= Daverio Rocchi [1994] 189 ff). 
the special relationship of Phocus with the sea, ${ }^{3}$ and that he moved to Tithorea (Paus. 2.4.3).

According to the scholia (schol. ad Eur. Or. 1094), this Phocus actually arrived with his father Ornytion at Hyampolis to help the Phocians against the Locrians: they were fighting for Daphnous which ensured for the Phocians access to the sea and the Euboic Gulf, while it ensured for the Locrians the unity of Locris. As the Phocians won, Locris was divided into two parts. After the victory over Daphnous, it became Phocian and a mythology was developed that linked the Phocians to the city of Daphnous: Schedius, the leader of the Phocians in the „Iliad“ (15.515), grandson of Naubolus (Paus. 2.29.2-3) and therefore descendant of Phocus (see below), was buried in Daphnous (Strab. 9.3.17).

The traditions often underline the connection of this Phocus with Tithorea (Paus. 2.4.3; 2.29.3; 10.1.1). ${ }^{4}$ According to these, the „first“ Phocus was very active in the cities of Hyampolis and Tithorea, which are situated in the northeastern part of Phocis. This observation is taken up by a geographer in the Hellenistic period, according to whom Phocus synoikised (ouvoıkíol) the Phocians after having arrived there from Corinth. ${ }^{5}$ What's more, Tithorea was torn between the Phocians and Thebans during the „Third“ Sacred War. ${ }^{6}$

The stories about the Corinthian Phocus were also developed to underline an enmity: that between the Phocians and Thebans. Indeed, Pausanias tells an interesting story in this regard. The Princess of Thebes, Antiope, had two children with Zeus while she was married to Epopeus. She was obliged to leave them and was persecuted by her uncle Lycus and his wife Dirce. The children of Antiope, Amphion and Zethus, tried to free her, and Dirce, a Maenad, was murdered; Dionysus therefore let Antiope go mad. Antiope started to roam through Greece until Phocus healed and married her. From this moment on, every year in spring, the inhabitants of Tithorea tried to steal soil from the grave of Amphion and Zethus in Thebes in order to dedicate it to the grave of Phocus and Antiope (Paus.

3 See also McInerney (1999) 127-147; Burnett (2005) 17-18; and, with caution, Polinskaya (2013) 133.

4 Modern research has for this reason assumed that the Hyampolitans were allied with the inhabitants of Tithorea: it was probably an alliance between Tithorea and Hyampolis against the

Locrians: in this conflict Tithorea played a major role. McInerney (1999) assumed that, from this moment on, Phocus became a hero for both cities, later also for Drymaia that was originally called Naubolus (Paus. 10.33.12). All this, however, is highly hypothetical, as Di Gioia remarks,

also because Phocus of Drymaia is not the Corinthian but the Aeginetan (cf. Paus. 10.33.11). Discussion in Di Gioia (2012) 212. See also Daverio Rocchi (2011) 30 (= [1999] 24).

5 [Ps.-Schymnus] GGM 483-487, with comment of McInerney (1999) 140-141.

6 Daverio Rocchi (2011) 54 (= Daverio Rocchi [1993] 5), who comments on schol. ad Demosth. 19,

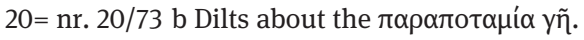


9.17.4). ${ }^{7}$ This also links with the struggles between the Phocians and Thebans during the „Third“ Sacred War, ${ }^{8}$ as will become clearer later on.

Pausanias (Paus. 2.29.3, 10.1.1.) is convinced that the country around Tithorea and Delphi was at first called Phocis from Phocus, the son of Ornytion, and grandson of Sisyphus of Corinth; and that the name is said to have been then extended to the whole country from Phocus, a son of Aeacus, who arrived there not long later. The „second“ Phocus comes from Aegina. ${ }^{9}$ He is mentioned for the first time in the „Theogony“ (11. 1002-1005) and described as the son of Psamathe and Aeacus. Aeacus already had two sons, Peleus and Telamon, who killed Phocus out of envy, and were therefore banished: Peleus and his family to Phtia, Telamon to Salamis. ${ }^{10}$ The reason for the murder of Phocus by Peleus is developed in order to express the enmity of the Phocians toward the Locrians, as a tradition, preserved by Antonino Liberalis (38.5), proves. Peleus wandered through many places and gathered a herd of sheep. A wolf, however, killed all his sheep. The same wolf was turned into a rock which forms the contested boundary between Phocis and Locris.

Pausanias sees in Aegina the grave of Phocus; his children, tells Pausanias, went into the area „now called Phocis“. ${ }^{11}$

\section{Phocus and Aegina}

As Anna Di Gioia has already showed, ${ }^{12}$ and McInerney too presumed, the traditions of a Corinthian Phocus are younger than the ones of an Aeginetan Phocus, even if the Corinthian tradition is then presented by Pausanias as older. Pausa-

7 Paus. 9.16; 10.32.10; Steph. Byz. s. v. Tı9opaía. Cfr. Burkert (1985) 212. For the grave of Amphion and Zetus, see Eitrem (1941) 498 and Symeonoglou (1985) 192-193 and 273-274. A „Dionysian“ interpretation of the rite was suggested by Rocchi (1986) 257-266, while Schachter (1981) 29 is rather sceptical about the tradition. Rutherford is, however, of the opinion that the traditions refer to a religious pilgrimage, which flourished in Antonius's times (Rutherford [2001 a] 40-51). Discussion in Di Gioia (2012) 12.

8 Daverio Rocchi (2011) 54 = Daverio Rocchi (1993) 5.

9 For the relations between Aegina and Phocus see schol. Pind. N. 7, 94 a Drachmann; Bona (1988) 99-141; Rutherford (2001b) 298-333; Kowalzig (2007) 181-222. According to Polinskaya (2013) 133 he cannot be a figure of Aeginetan mythology as he is rarely mentioned in the local Aeginetan traditions.

10 See also Pind. N. 5; Eur. Andr. 687; Ov. met. 7.477-479; 11.268-270; 11.379-380. Cfr. Prinz (1979) 47; McInerney (1997) 142; and mainly Polinskaya (2013) 152 and 425-435.

11 Paus. 2.29.2-9.

12 Di Gioia (2012) 6. 
nias's source for the Aiacid Phocus, however, is Asius (fr. 5 West = Paus.2.29.424), suggesting that the tradition had already developed by the $6^{\text {th }}$ century; and a Phocus of Aegina is mentioned by Hesiod (Hes. theog.1003-1005 MerkelbachWest), in the catalogue of women and in the Alcmeonis (Alcm. fr. 1 Bernabe = F 1 West [apud sch. Eur. Andr. 687 Schwartz]). ${ }^{13}$ Of course, it is not easy to define when this Aiacid Phocus began to be connected with Phocis. However, the Nekya of the Lesche of the Cnidians seems to provide a clue. In the Nekya there is mention of a journey to, or at least a stay in, Phocis: indeed, many scholars maintain that the couple above and to the left of Patroclus, described by Pausanias in the Nekya of the Lesche of the Cnidians of Polignotus, represents Phocus and Iaseus. ${ }^{14}$ It would be useful then to take into account the chronological context of the Lesche. The Lesche of the Cnidians was built in the years between 475-460 and then in a second moment in the $4^{\text {th }}$ century; it was presumably painted by Polignotus of Thasos; just a few remains of the Lesche are preserved, ${ }^{15}$ but they are described in detail by Pausanias (10.25.1-31.12). ${ }^{16}$ As Di Gioia remarks, ${ }^{17}$ this tradition about the encounter of Phocus with Iaseus is to be linked to the victory at

13 In the iconographic sources, the Aeginetan Phocus is represented only from the $5^{\text {th }}$ century on: on an Etruscan scarabaeus, in the Etruscan version Puce (with inscription) from the first half of the $5^{\text {th }}$ century, where his death is represented by a spear (London, British Museum, Inv. FR 3 06; Brunn [1860] 235; Smith [1888] 498; Furtwängler [1900] 99, fig. 20; Marshall [1907] nr. 306, fig. 19; Pauli [1902-1907] 3272; Enking [1959] 1038; Caprino [1960] 870, as it is about Hyacinthos; Camporeale [1965] 589; De Simone [1968] 105; Cristofani [1983] 316-317, n. 269); and in the Nekya in the Lesche of the Cnidians of Polignotus, with Iaseus - yet even in this case it is not necessarily the Phocus of Aegina, although the research assumes so.

14 Iaseus is a Phocian whom Phocus befriended after his immigration (Robert - Preller [1854] 831-832; Robert [1892] 81-82; Eitrem [1941] 499; Kebric [1983] 29; Stansbury-O’Donnell [1990] 221 fig. 4, 223-224, 231, 233).

15 Pouilloux (1960); Stähler (1989) 15-17; Cousin (2000) 61-103.

16 It is to be noted that the representation of Phocus is designed in the way of a „national“ hero by an upcoming population: Pausanias tells us (10.30.4) that „Iaseus, the Bearded“ was given a ring by Phocus, who is represented as a youth and without a beard (the young age of Phocus in the Nekyia is already pointed out by Weniger (1902-1909) 2410-2412): here we have, at least in the representation of Pausanias if not in the tradition that he is drawing on, the symbolism of anthropopoiesis. The immigrant Phocus is a candidate for the anthropopoiesis up until the point that he reaches adult age, i. e. „becoming Phocian“. His representation is formed together with other representations in the Phocian narrative, as e. g. the one of the Phocian leaders during the so-called $3^{\text {rd }}$ Sacred War, creating a network, a discursive strategy that builds up the pattern of anthropopoiesis.In the socialisation rites the beard - or being without a beard - is regarded as a symbol: in some cases a youth's first beard is even dedicated to a divinity (Anth. Pal. 6.242; Leitao [2003] 115 with literature).

17 Di Gioia (2012) 11. 
Eurymedon $^{18}$ or the one at Oenophyta ${ }^{19}$ and probably developed in the Cimonian area, where the friendship, and not the kinship - and therefore not the co-responsibility - of Peleus and Telamon was highly regarded (Pherec. FGrH 3 F $60=$ Apollod. 3.158). ${ }^{20}$ If all this is true, the link of the Aeginetan Phocus to Phocis actually goes back to the first half of the $5^{\text {th }}$ century.

The connection of a hero named Phocus with Corinth, on the other hand, is relevant because of the context of the sources in the $4^{\text {th }}$ century.

\section{Phocus and Corinth}

The topic is complex and for reasons of clarity it will be explored in a schematic way. There are in fact at least 6 reasons to hold that the link between Phocus and Corinth becomes relevant just after the $4^{\text {th }}$ century:

a. First of all, it is to be considered that the first time a Phocus of Corinth is reported is very probably in Ephorus, who presumably is the source of PseudoScymnus. ${ }^{21}$ We can possibly assume that it is an older and established tradition: Ephorus would have hardly opposed Hesiod, who talked about a Phocus of Aegina, and not of Corinth (theog. 1002-1005), if he hadn't known about a solid and coherent tradition. ${ }^{22}$ This might, however, be just an assumption. Quite undisputed is, on the other hand, the opinion that PseudoScymnus picks up on Ephorus. And Ephorus indeed writes in the $4^{\text {th }}$ century.

b. That more than one hero called Phocus was known in classical times is confirmed not only by the iconographical sources, ${ }^{23}$ which go back to the archaic period, but also - and even more strongly - by the scholium A at Hom. Il.

18 The victory at Eurymedon was important for the Cnidians, and the Cnidians wanted to underline their friendship with the Phocians: Iaseus was Iasus, son of Triopas and founder of Cnidus (Robert [1892] 81-82). See also Pouilloux (1960) 137-138; Kebric (1983) 2-13.

19 The battle in Oenophyta would have given the Phocians the control of Delphi with it its consecrations (Thuc. 1.107-108; Diod. 11.79; Strab. 9.3.15): Manoledakis (2003) 2-13.

20 Theopompus mentions this Phocus too: Myth. Hom. 4096 fr. 1 Schubert. See Biagetti (2012) 27-34. 21 See, mainly, Jacoby FGrH II C Kommentar, Berlin 1926, 22-34; Marcotte (2000); Bravo (2009) 18-19; Korenjak (2012).

22 N. 4, 14.

23 A black-figure Attic dinos (580-570 BC), on which are represented the funeral games in honour of Pelias where an individual is marked by an inscription as Phocus: Athen. Mus.15466; Pease (1935) 226-228; Roebuck (1940) 146, n. 1; Immerwahr (1998) n. 71 c. 22; a black-figure Attic amphora (private property) ( $570-560 \mathrm{BC}$ ), where a fighter observing the duel between Achilles and Mnemon is described by an inscription as Phocus (Von Bothmer [1977 a] 51-63; Von Bothmer [1977] 251-253); a black- figure Attic hydria (Wien KHM IV 3614; Kurtz [1971] 43; Burn - Glynn [1982] 29, n. 106.I) from 
$2.517^{24}$ : here is mentioned a Phocus who is the son of Poseidon and Pronoe (a Nereid, like Psamathe). This firm belief is to my knowledge attested in this form only in this scholium; in Pausanias (2.4.3) it is represented as an option in the genealogy of the Corinthian Phocus. The conviction attested in the scholium most probably was forgotten as it was substituted by another conviction according to which the second Phocus was of Corinth. ${ }^{25}$ In fact, the establishment of this second Phocus in the Corinthian genealogy happened later, after the $5^{\text {th }}$ century; moreover, it was forced. A comparative analysis, even a superficial one, of the genealogies of the two heroes called Phocus confirms this:

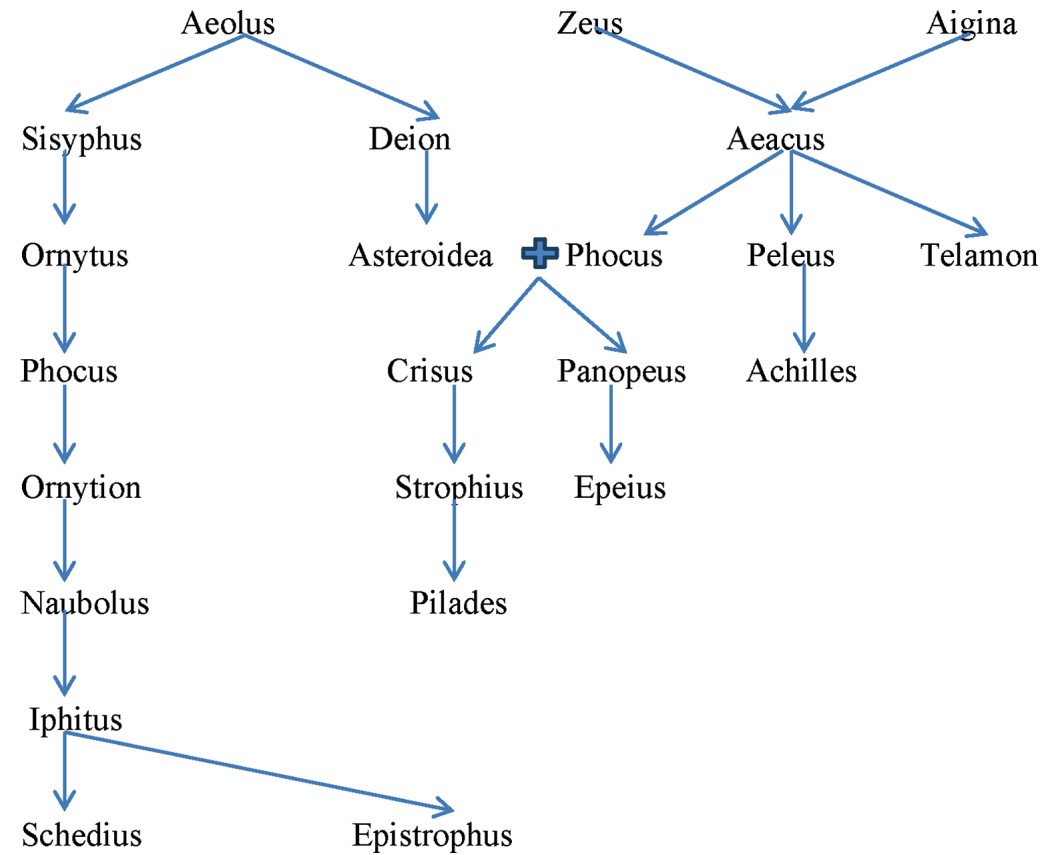

Figure 1

Cerveteri, dating back to about 560, representing the killing of Troilus by Achilles where a fighter is described by an inscription as Phocus (Masner [1892] 24 n. 221; Bates [1907] 432 fig. 3; Heidenreich [1951] 116 n. 17; Zindel [1974] 44, 107 n. 5; Bérard [1983] 24 fig. 15; Raeck [1984] 2-3 fig. 1).

24 It is in fact a scholium D, i. e. it belongs to the scholia which were erroneously called D after Didymus, but actually depend on school material of classical times, especially word explanations that are quite comprehensive (see Gudeman [1921] 630; Dickey [2007] 20; Van Thiel (2002) 2-3, 5; Van Thiel [2000b] 2).

25 Therefore, Pausanias claims (2.4.3) that according to some the Corinthian Phocus is the son of Poseidon. 
It is evident that, from Ornytus on, the family tree was defined artificially: the controversial points in the genealogy are numerous, as results from an overview of some genealogical links:

- According to Hesiod (theog. 1003-1005), the Aiacid Phocus married Asterodeia

- Asterodeia is the daughter of Deion (cat. fr. $58 \mathrm{M}-\mathrm{W}$ ), who is the son of Aeolus (fr. 10 a, $28 \mathrm{M}-\mathrm{W}$ ).

- Deion was in turn the brother of Sisyphus but also of Cretheus (Od. 11.236ff; cat. fr. 4 [=Plut. Mor. 747]).

- Cretheus married Tyro. They had three children (Aeson, Pheres and Amythaon) and Tyro already had two children with Poseidon (Pelias and Neleus);

- $\quad$ the son of Aeson is Jason (cat. fr. 13 = schol. Hom. Od. 12.69; Apollod. 1.9.11; Diod. 4.6.8.3).

What one can infer is that Cretheus lives two generations before the Argonauts, and we must consequently assume the same for Deion.

This last point, however, is problematic with regard to the genealogies of the two ,Pausanian“ Phocuses, as the generations of Argonauts on the side of the Aiacid Phocus do not correspond with the ones on the Corinthian side. On the Aiacid side, there is the contradiction of the genealogical position of Peleus, Phocus's brother, who married Asterodeia: Peleus is an Argonaut. On the Corinthian side, the contradictions are even more striking: Iphitus, Nabulus's son (Il. 2.518), is an Argonaut (Apoll. Rhod. 1.207ff), but he appears five and not two generations after Deion: Ornytus, Phocus and Ornytion seem to be superfluous in this genealogy. In the following scheme (see next page), in which the Argonauts are underlined, this should become clearer.

One wonders if these difficulties are linked to the fact that the „Corinthian“ genealogy was only composed late and linked in a clumsy way with that of the Aeginetan Phocus. In fact, the redundancy of Ornytus, Phocus and Ornytion is confirmed by the circumstance that it is cited only in the exegetic scholium b of „Iliad“ 2.517, (possibly already at Ephorus ([source of PseudoScymnus?]), in contrast to Sispyhus (e. g. Hes. fragment 43 a), Naubolus (Il. 2518), Iphitus (Il. 2518) and Schedius (Il. 2518), which are already mentioned in archaic epic. This fact also gives us some hints about the chronological context of the invention of a Corinthian Phocus: the establishment of the second' Phocus in the Corinthian mythology is not archaic and perhaps not even classical (cf. time period of scholium D):

a. In describing the actions of a Phocus of Corinth, Pausanias mentions an oracle as well, which describes a certain rite: every year in spring, the inhabitants of Tithorea stole some soil from the grave of Amphion and Zethus in 


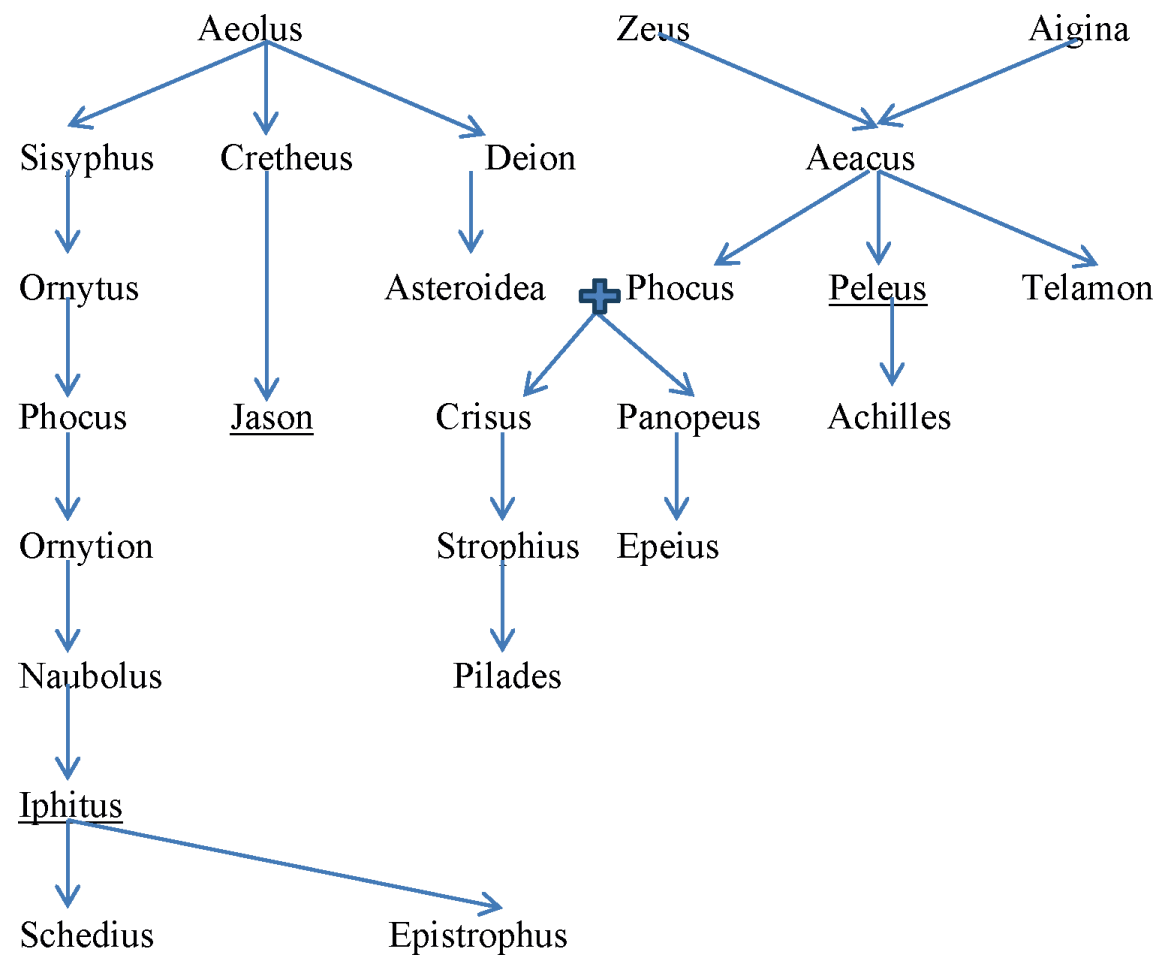

Figure 2

Thebes in order to dedicate it to the grave of Phocus and Antiope (Paus. 9.17.4). Phocus is cited in the text of the oracle, and the oracle itself is ascribed by Pausanias to Bacis. The Bacis which Pausanias refers to here and in other cases $^{26}$ comes from Boeotia and his oracles all concern the history of Boeotia. Most of Bacis' oracles about Boeotia date back to the $4^{\text {th }}$ century. ${ }^{27}$

b. The second marriage of Antiope to Phocus is, from the point of view of the development of the history, only then possible if the episodes of Antiope's wanderings and Dirce's persecution had been developed. To our knowledge, these episodes are attested since Euripides in the tragedy Antiope,${ }^{28}$ which

26 In the old tradition, however, (at least) 3 Bacides are documented: cfr. schol. Pax 1071. See Prandi (1993) 52; Asheri (1993) 64 with literature.

27 Fontenrose (1978) 145ff; Asheri (1993) 64 with literature. Cfr. Paus. 4.27.4; 10.12.11.

28 Kühr (2006) 84, 118ff, and mainly $122 \mathrm{ff}$ with sources and literature. The wandering episode is not to be found in Hom. Od. 11.260-265; Asius F 1 PEG; Pherecyd. FGrH 3 F 41 a-b. 
was performed for the first time between 405 and $401^{29}$ and was attested in iconography from the $4^{\text {th }}$ century on. ${ }^{30}$

c. In those representations of Antiope's persecution and the involvement of a Phocus which are older, the identifications of Antiope and Phocus are highly problematic. $^{31}$

d. A final consideration provides the answer to the question of why from a certain moment on, most probably the $4^{\text {th }}$ century, Phocus should have been connected with Corinth. In fact, in the case of the Aiacid Phocus, Irene Polinskaya and Anna Di Gioia ${ }^{32}$ have shown that originally these traditions are Phocian, ${ }^{33}$ and that later they are taken up by the Aeginetans in order to claim affiliations to Delphi, to be then elaborated and used in a panhellenic sense. In the case of the Corinthian Phocus, it is likely that it is neither a tradition that was passed on in the Korinthiaka, as Will assumed, ${ }^{34}$ nor an ,originally Phocian tradition about an ,originally، Phocian figure, whom already Ephorus might have talked about and who later enters into a Corinthian tradition, as McInerney and Di Gioia maintain. It is rather to be assumed with

29 Gibert (2009) $25 \mathrm{ff}$.

30 Taplin (1998) 33-39.

31 An Attic red-figure vase (CVA Kiel I Antike Samml. 30042) which goes back to the time between 475/425 represents a male and a female figure, which are usually identified as Theseus and Helene (Shapiro [2000] 274 with literature) but which Mannack takes to be Phocus and Antiope because the representation displays many similarities with the one on the Vienna Hydra (cfr. Simon [1994] 856; Mannack [2001] 95). The identification with Antiope and Phocus is more probable, if not completely unproblematic, in the following cases: a picture in the tablinum of the house of Meleager in Pompeii (Napoli MN 112283, 20 BC: Panofka [1855] 3; Wernicke [1894] 2497; Schefold [1957] 14; Simon [1994] 856-857); and a bronze rhyton of the early imperial period (Berlin Staatliches Museum 30492; see Tuchelt [1962] 132; Schefold [1964] 170-171; Hoffmann [1966] 123-124; Greifenwagen [1977] 19-26; Simon [1994] 856; Froning [1981] 153-156; KossatzDeissmann [1992] 322-329); the representation of Antiope's wandering and the encounter with Phocus is, on the other hand, rather clearly shown in a red-figure Attic scyphus (Wien KHM 382) of the late $5^{\text {th }}$ century, where a female figure who is fleeing is described by an inscription as Antiope, and an individual, without inscription, could be interpreted as Phocus (Jahn [1853] 104-105; Panofka [1855] 1-13, 12; Simon [1994]; CVA, Taf. 42 S. 34; Weniger [1902-1909] 2411): this representation on the scyphus is, however, rather isolated and actually dates back only to the late $5^{\text {th }}$ century.

32 Polinskaya (2013) 133; Di Gioia (2012) 10.

33 Or at least not necessarily Aeginetan: according to Polinskaya there were more heroes called Phocus, in Phocis as well as outside, and they were then united: Polinskaya (2013) 133; contra, Kowalzig (2007) 203, who believes that Phocus of Aegina was originally a figure of Aeginetan mythology who then was linked with Phocis during the so-called First Sacred War because Aegina was probably involved in this war.

34 Will (1955) 239. 
Polinskaya that in the old traditions there existed many Phocuses, as proved by literary sources ${ }^{35}$ and iconography. ${ }^{36}$ The question arises as to when and why the Corinthians were interested in adopting a hero called Phocus. This is our sixth point, which will be developed in the next paragraph.

\section{Phocus and the Corinthian stasis}

As the Corinthian Phocus had the function of expressing the relationship with Thebes on the one hand and with the Locrians on the other hand, it is necessary to briefly sketch out the relationships which existed between the Phocians, Corinthians, Thebans and Locrians. What must be kept in mind is that Daphnous plays an important role in the history of the Corinthian Phocus: as described above, it is thanks to Phocus that Daphnous becomes Phocian after a conflict against the Locrians. This is interesting because the Phocians and Locrians fought against each other several times and on various frontiers, especially between the $4^{\text {th }}$ and the $2^{\text {nd }}$ century BC. ${ }^{37}$ In 395 BC, however, there occurred a conflict between the Phocians and Locrians which is considered to have been the reason for the Corinthian War, as also Di Gioia notes. ${ }^{38}$ The more interesting thing is that this conflict involved, among others, also the Thebans. It is highly probable that in this period a hero called Phocus was anchored in Corinthian mythology.

35 They are extensively discussed by Weniger who also takes into consideration the eponymous hero of Phocaea (Heraklid. fr. 38) and the father of Callirhoe from Ctesias in Boeotia: the latter had repeatedly postponed the marriage of his daughter until the suitors killed him. The suitors then persecuted Callirhoe and were besieged by the Thebans as punishment. The night before the capture, a voice was heard coming from Cithaeron, saying „I am here“; it was claimed to be

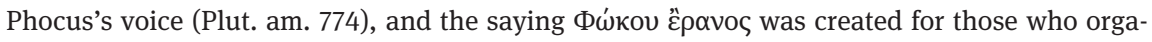
nized banquets to their own detriment (Plut. prov. Ac. 123; Zenob. 6.37; Diog. 8.66; Apost. 18.5; Arsen. 56.66; Suda s. v. Phokos). Eitrem, furthermore, cited a Phocus as a participant in the Argonauts' trial (Hyg. fab. 14.9) and an Athenian of the $6^{\text {th }}$ century who is mentioned in Plut. Sol. 14 .

36 The black-figure Attic dinos (580-570 BC) on which are represented the funeral games in honour of Pelias where an individual is marked by an inscription as Phocus (Athen. Mus. 15466); the black-figure Attic amphora (private property) (570-560 BC), where a fighter observing the duel between Achilles and Mnemon is described by an inscription as Phocus (Von Bothmer [1977 a]; Id. [1977 b]); the black-figure Attic hydria (Wien KHM IV 3614; Kurtz [1971] 43; Burn Glynn [1982] 29, n. 106.I) from Cerveteri, dating back to about 560, representing the killing of Troilus by Achilles where a fighter is described by an inscription as Phocus. See above, n. 21.

37 Daverio Rocchi (1988) num. 12; Rousset (2002) 288-291; Daverio Rocchi (2011) 55 (=Daverio Rocchi [1993] 5).

38 Xen. hell. 3.1; Hell. Oxy. 21.2-3 Chambers; Paus. 3.9.9; Daverio Rocchi (1988) 132-142, esp. 134-135; Rousset (2002) 162-164, esp. 162 note 604. 
The initiators of the war were the Theban leaders Androcleidas and Ismenias, who had convinced the Phocians to attack Locris (according to Hell. Oxyrh. 21.2-3 Chambers; Paus. 3.9.9), or had induced the Locrians to exploit the contested area in order to provoke a reaction by the Phocians (Xen. Hell. 3.1). Xenophon refers to an area around Parnassus which was contended by the Phocians and the western (Ozolian) Locrians; the Hellenica Oxyrhynchia, however, refer to the Opuntian Locrians; Pausanias (3.9.9; see also Diod. 14.81.1) is ambiguous. ${ }^{39}$

Di Gioia's conclusion could be further developed. That the Corinthians adopt Phocus at this time is linked to the fact that this conflict was conducted against the Locrians, but also that there was a stasis in Corinth. Besides, this can explain why this Phocus became Corinthian and not e.g. Theban.

Corinth was in an alliance with Sparta from the $6^{\text {th }}$ century on. This began to falter after the Peace of Nicias as a Sparta-critical attitude arose. At the time of the outbreak of the Corinthian War, we get to know about anti-Spartan powers (Diod. 14.82.2 $)^{40}$ which were comprised partly of former Laconian-supporting politicians like Timolaus and partly of „democratic“ groups (Hell. Oxyrh. 2.3; Diod. 14.86.1); they were worried about suffering from disadvantages through the consequences of the growing power of the Spartans in the years of the Spartan hegemony after the Peloponnesian War (Hell. Oxyrh. 2.3). ${ }^{41}$

In the autumn of 395, the Corinthians made an alliance with Argos, Thebes and Athens. In Nemea, 3000 Corinthian Hoplites fought against Sparta (Xen. hell. 4.2.17). However, the victory of Sparta in this battle brought a strengthening of the pro-Spartan side with it. ${ }^{42}$ In the following months, they profited from the desire for peace in Corinth, in whose areas the war mostly took place. In order to prevent a change, prodemocrats enemies of Sparta massacred their enemies during the festival of Artemis Euclea (Xen. hell. 4.4.6; Diod. 14.86.1). ${ }^{43}$ A democracy was established (Xen. hell. 4.4.6) (4 $^{4}$ and it was decided to join Argos, maybe in the

39 The sources don't agree about which Locrians were involved: the Opuntian (Xen. hell. 3.5.3) or the Oziolian (Hell. Oxy. 13.3ff and perhaps also Paus. 3.9.8 ff). See Busolt (1908) $277 \mathrm{ff}$; Meyer (1909) 81 ff; Schober (1924) 67; Cloché (1952) 101 ff; Perlman (1964) 64ff; Larsen (1968) 158; Funke (1980) 54 and n. 25; Cartledge (1987) 291 ff; Lendon (1989) 300-313, 300 ff; Buck (1994) 32 ff. Cfr. especially Beck (1997) 112 who discusses this literature about the Corinthian war.

40 Gehrke (1985) 82.

41 Gehrke (1985) 83.

42 Gehrke (1985) 84.

43 Gehrke (1985) 85.

44 O’Neill (1930) 145; Gehrke (1985) 85. 
form of an isopolitia. ${ }^{45}$ A bloody battle took place in Lechaion: Spartans and Sycionians defeated the Corinthian democrats, Argives, mercenaries under Iphicrates and the Boeotians (Xen. hell. 4.4.9ff; Diod. 14.86.2ff).

In this way in the following years, as the war was waged almost exclusively in the territory of Corinth (Diod. 14.86; Xen. hell. 4.4, $18 \mathrm{f}$.) and the split which divided the parties waging war continued right through the population of Corinth, there were effectively two Corinths, which existed only due to the mercy of the Spartans or the Argives. ${ }^{46}$ Gehrke observes that this is attested by the dispute about the holding of the Isthmian Games in 390 (Diod. 14.86.5; Xen. hell. 4.5.1ff; Plut. Ages. 21.3 ff.; Paus. 3.10.1.; Aristeid. 22.7 Keil): the games were started by the Argives who were allies of the Corinthians, but then Aeschilus appeared with an army together with emigrants from Corinth and the games were carried out under his protection. ${ }^{47}$ Among the democrats, there was in fact a strongly pro-Argive group, which caused the synoikism with Argos, so that Corinth formally lost its public identity (Diod. 14.92.1ff; Xen. hell. 4.8.34); ${ }^{48}$ but as Corinth became independent after the King's Peace, these democrats had to emigrate (to Argos: Diod. 15.40.3, and to Athens: Demosth. 20.54) and the pro-Spartan oligarchs gained power again.

Summing up, the result of these events is that until the King's Peace there were two groups in Corinth: one was oligarchic and pro-Spartan, and would definitively come to power again after the Corinthian War. The second group was „democratic“ and anti-Spartan; it was also pro-Argive and allied with Thebes and Athens and became so powerful during the Corinthian War that they brought it to the synoikism with Argos. If we consider these alliances from a Phocian point of view, we can observe that the position of the Phocians in this constellation was strong. The Phocians were allied with Sparta and were supported by Sparta against Thebes in the above-mentioned conflict against the Locrians. ${ }^{49} \mathrm{~A}$ short summary of the events after the end of the Peloponnesian War on the Phocian side allows a better comprehension of the relevance of this constellation. Athens was weakened and the Phocians consequently started to rely more on Sparta. As McInerney observed, this alliance brought advantages for both: the Phocians disposed of a large power which supported them, the Spartans of a base in Central

45 Gehrke (1985) 85.

46 Gehrke (1985) 86.

47 Gehrke (1985) 87.

48 Gehrke (1985) 87.

49 Xen. hell. 3.5.4ff; Hell. Oxy. 13.4; see Schober (1924) 67ff; Perlman (1964) 66 and n. 6; Funke (1980) 54; Buck (1994) 35ff; Beck (1997) 112. 
Greece. ${ }^{50}$ As the conflict with the Locrians broke out, the Thebans marched into Phocis and attacked Daulis, Panopeus and Parapotamioi; then they marched on to Elateia, Pedieis and Hyampolis. The Spartans helped and Lysander led an army in Phocis to support the Phocians. At the beginning, the Spartans were successful against the Thebans, but in Haliartus Lysander died (Xen. hell. 3.5.6-25; Plut. Lys. 28-29). ${ }^{51}$ Phocis remained a strategically important area for the Spartans. In the Locrian city of Naryx, next to the Phocian Triteis and Elateia, at the border between Phocis and Locris, the Boeotians fought against an army of Phocians and Spartans whose leader was Alcisthenes (Diod. 14.82.5-10). In 394 BC Agesilaus returned from Asia Minor, then set out for Phocis in order to march directly to Boeotia. After the battle of Coroneia, the Spartans fled to Phocis (Xen. hell. 4.3.15; Xen. Ag.).

It is therefore very likely that the traditions about the two heroes called Phocus were rearranged in a way that would express the Corinthian enmity towards Thebes and Locris which built to a climax at the beginning of the fourth century. This does not rule out the possibility that other struggles between the Phocians, Locrians and Thebans also influenced the fluidity of Phocus' genealogy: the one at Tithorea between the Phocians and Thebans during the „Third“ Sacred War could provide a good example. ${ }^{52}$

\section{Phocus, the Phocians and the Thessalians}

A closer analysis reveals a further connection. The genealogies of both the Corinthian and the Aeginetan Phocus could also perform the function of expressing the relations with the Thessalians. According to Di Gioia, this could be interpreted in relation to the ambitions on Delphi, as the claims on Delphi as well as those on Thessaly could have panhellenic implications. ${ }^{53}$ It is useful to go further. These relations were indeed forged in enmity, ${ }^{54}$ and the Phocians once really ran the risk of being turned into penestai. They reacted in two ways: they fought, but on


The puzzling genealogies of Phocus can become of interest in this regard.

As far as the Corinthian Phocus is concerned, it is in any case relevant that Sisyphus was the son of Aeolus, whose homeland is Aiolis in the south of Thes-

\footnotetext{
50 McInerney (1999) 194.

51 Beck (1997) 112.

52 Daverio Rocchi (2011) 54 (=Daverio Rocchi [1993] 5).

53 Di Gioia (2012) 7.

54 On this enmity, see mostly Lehmann (1983) 35-43.
} 
saly (Hom. Il. 6.154). The link between Phocians and Thessalians was also enhanced by the fact that one of Sisyphus's brothers was Deion, ${ }^{55}$ who according to later sources was king of the Phocians (Apollod. 1.86). ${ }^{56}$

Ties with Thessaly are also suggested in the genealogy of the Aiacid Phocus. Peleus's name means „man from Pelion“, and Wilamowitz deduced that Aeacus, father of Peleus, and the Myrmidons, whose king is Peleus (Il. 24.536), did not originate in Aegina but in Thessaly. ${ }^{57}$ Polinskaya points out the relation to Thessaly even more strongly: she is of the opinion that originally there existed two Aeacuses, one in Aeginetan mythology, another one in Homeric epic. The first fused with the second, and in this way Phocus of Aegina became the father of

55 Hes. cat. fr. 10 a, 28 M-W, cfr. West (1983) 29; West (1985) 64; comment in Di Gioia (2012) 4. 56 Similarly it becomes relevant in this context that between Daulis and Delphi there was a city which was called Aiolidai and which was destroyed by the Persians in 480 according to Herodotus (Hdt. 8.33). And it is of much more interest that the Kragallidai, Dryopians and Phlegyans are also linked to Thessaly. One wonders where the link is between them and the Phocians. Well, there is an important link: the Kragallidai, Dryopians and Phlegyans lived (according to the predominating tradition) on Parnassus and were described as Phocians by later traditions as they desecrated Delphi in the same way the Phocians did in the so-called „Third“ Sacred War. The Kragallidai, a people living in Crisa and disappearing in the First Sacred War (Aischin. 3.117; Hesych. s. v.), were of Thessalian origin: they are the descendants of Kragaleus, the son of Dryops, and their country of origin was Dryops. About this country of origin, the traditions disagree: according to Herodotus $(8.31 ; 8.43)$ and Strabo (8.6.13), the Dryopians came from Doris, next to Parnassus; according to Pausanias (4.34.9-10) from Lycoreia (from Parnassus); according to a scholium of Apollonius Rhodius (1.1212-1219 d Wendel; see also Etym. m. s. v. Dryops) from Parnassus, but according to another scholium to Apollonius Rhodius (1.1212-1219 a) and Strabo (8.6.13) from Trachis in Malis, on the Oeta and in the valley of Spercheius, i. e. in Thessaly. This scholium and Strabo testify to a further tradition which sets the main seat of the Dryopians not on Parnassus but in Thessaly: they are brought to Thessaly by Heracles in order to civilize them (1212-1219 a).Of course, this does not automatically mean that the country of origin of the Kragallidai was Thessaly, as, according to Stephanus of Byzantium (s. v. Crisa), there existed two other cities called Crisa: one in Troas and one in Aiolis (McInerney [1999] $135 \mathrm{ff}$.). But what is certain is that at some point a link between the Dryopians and Thessalians was established. As far as the origin of the Phlegyans is concerned, sources are ambiguous: they are often described as Phocians or Boeotians, but the most ancient sources described them as Thessalians. Pherecydes

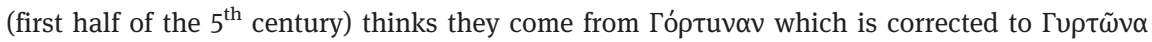
(FGrH 3 F 41 e Schol. A Gen II Il. 13.302=41 c FOWLER). Apollodorus says that Phlegyas is son of Ares and Dotis: Dotis is a Boeotian woman, but her name perhaps refers to the $\Delta \dot{\omega} \tau$ เov $\pi \varepsilon \delta$ íov which is in Thessaly (3.5.5). It is also of some interest that according to another passage of the Library (3.10.3.6) Phlegyas and his daughter Koronis lived in Thessaly. See also [Hom.] Hymn. Apoll. 16; schol. Apoll. Rhod. 1.57; Crates of Mallos, fr. 17 Broggiato; see Franchi (2013) 450-458; ead. (forthc.).

57 von Wilamowitz (1931) 220; Lesky (1937) 272; McInerney (1999) 145 ff. 
Peleus. ${ }^{58}$ The relationship of Peleus himself with Thessaly has been emphasised since Homer. The marriage to Thetis takes place on Mount Pelion (Kypria F 3 EpGF; cfr. Hom. Il. 23.277ff; 24.59-63; Eur. Iph. A. 704-707; 1076-79; Catull. 64, 265-302); he sends his son Achilles to Chiron (Il. 11.831), who lived in a cave at the feet of Mount Pelion in Thessaly (so already in Cypria fr. $2 \mathrm{~K}$ and Hes. cat. fr. $38 \mathrm{~K}$; see also Pind. P. 3.1ff). From Phtia, he sends Achilles to help Agamemnon (Il. 9.4.38); Menthios is supposed to be the son of the River God Spercheius and Polydora, daughter of Peleus (Il. 16.175); the punishment of Peleus by Acastus, whose wife had fallen in love with Peleus, as later sources report (Pind. N. 5 2536cfr. with Apollod. $3.164 \mathrm{ff}$ ), is already described in archaic times (Ehoiai 209): he is left back at Pelion where he is rescued by Chiron. Most of all, however, it is crucial that in Homeric epic Peleus is a native of Thessaly: Peleus is defined as King of the Myrmidons (Il. 24.536) and these were from Thessaly (Il. 21.188; Od. 3.188), from Phtia (Il. 1.179). The fratricide has already been referred to above. Pindar already knows this history (N. 5.10-15 12; cfr. Alcmaionis fr. 1 Bernabé; Eur. Andr. 687; Ov. met. 7.477-479; 11.268-270; 11.379 ff.), even if he just alludes to it; in Pindar, a note is found which links Peleus to Thessaly: Peleus should have conquered Iolcus for revenge because he had been left back on Pelion (N. 3.3234). According to the Iliad scholium (Il. 7.14; cfr. also Schol. ad Pind. N. 5.12), moreover, Peleus's mother, Endeis, was not the daughter of Sciron but of Chiron. This Aiacid Phocus moves in the Ehoiai to the Thessalian Phylace (Ehoiai $58 \mathrm{M}-\mathrm{W}$ ) and the daughter of Deion: and Deion is, according to Apollodorus, the King of the Phocians (Apollod. 1.86).

McInerney describes very well this dynamic change of the genealogy of heroes called Phocus in the Thessalian interest. He interprets it, however, as a hint about a real Thessalian origin of people included in these genealogies. As remarked above, it is quite evident that some heroes called Phocus are anchored only in a later period of Aeginetan or Corinthian (or even another) mythology. To interpret the hints and allusions to Thessaly in the genealogies of heroes called Phocus as denoting a real Thessalian origin of Phocus is, however, daring. Perhaps it could be assumed that the dynamic change of the genealogy can rather be interpreted as an intentional rearrangement by which the Phocians, amongst others, claimed to originate from a northern region and therefore to be homoioi with the Thessalians, as the above-mentioned passage by Herodotus proves.

58 Polinskaya (2013) $428 \mathrm{ff}$. See therefore also Gantz (1993) 220ff with sources. As son of Zeus: Il. 21.189 (mother is not mentioned); as father of Peleus (Il. 21.189); as husband of Psamathe and father of Phocus (Hes. theog. 1003-1005); as husband of Endeis and father of Telamon (Pind. N. 5.1-12; Bacch. 13.96-99); that Telamon and Peleus were brothers seems to be a presumption of Alkmaionis fr. 1 PEG. 


\section{Phocus east and west}

A last point seems to be of interest regarding the fluidity of the genealogies of the heroes named Phocus: the relationship between eastern and western Phocis. Indeed, the traditions about the heroes named Phocus sound like a claim of union, as already Giovanna Daverio Rocchi observed. ${ }^{59}$

Some stories about the Aiacid Phocus seem to hint at this claim. In fact, through his descendants, the Aiacid Phocus became a means of expression of the ambitions of eastern Phocis for an expansion of their power towards western Phocis: Phocus was indeed the father of the twins Crisus and Panopeus, who is in turn the father of Epeius, the builder of the Trojan horse. Panopeus was the founder of the city that is named after him. ${ }^{60}$ Crisus and Panopeus already hated each other in the womb, and Panopeus seems to have been the aggressor. ${ }^{61}$ East attacked west.

That the traditions about the homonymous heroes express the intention of the Phocians to regain control of a single area of Phocis, which extends from the Euboic Gulf in the east to the Corinthian Gulf in the west, i. e. from sea to sea, is also attested by the name „Phocus“ itself, as becomes clear from the following points:

59 Daverio Rocchi (2011) 29-30 (=Daverio Rocchi [1999] 23).

60 Paus. 10.4.1; Steph. Byz. s. v. Panope; schol. ad Il. 2.520; Eust. ad Il. 2.520 (274, 31-39).

61 Cassola (1980) 415-439, assumes for this reason that it is an anti-Panopeian Crisian tradition. This seems to imply that it is an archaic tradition, as Crisa was destroyed after this war, and is therefore not really worthy of support: it can be assumed that the „godlessness“ (asebeia), ,presumption“ (hybris), „lawlessness“ (paranomia) and „temple robbery“ (hierosylia) were charges against the Phocians already during the First Sacred War. However, it cannot be a coincidence that those sources about the First Sacred War which report such charges are sources from the $4^{\text {th }}$ century BC or later (e. g. Aischin. 3.107-113, esp. 107. 108 and 109; [Thessal.], Presb. (27), 7; Plut. Sol. 11; Paus. 10.27.4-8, esp. 5; Hypoth. Pind. O. p. 7 Drachmann; cfr. Davies (1994) 193-212, and Sánchez (2001) 68, 72, while earlier sources in which, according to some researchers, are to be found allusions to this war , i. e. [Hom.] Hymn. Apoll. 540-544 (Forrest [1956] 33-52, 34 with literature) and Hes. Scut. 478-480 (Parke - Boardman [1957]), don't mention the above cited charges. Before the $4^{\text {th }}$ century, the Phocians are not mentioned in the sources about the Phlegyans who destroyed the temple in Delphi and probably therefore this is to be interpreted in connection with the First Sacred War (Prandi [1981]; Ellinger [1993] 315 ff): cfr. ([Hom.] Hymn. Apoll. 16; Pherecydes (FGrH 3 F 41 d ap. Schol. T Hom. Il. N 302). One could ask whether these charges were only linked to the Phocians after the Third Sacred War, more specifically to those Phocians who fought in the First Sacred War (Sánchez [2001] 72). 


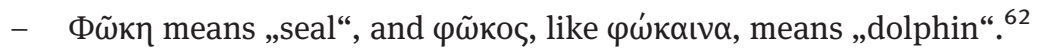

- Psamathe, a Nereid, took, according to the Euripides scholium, the form of a seal in order to flee from Aeacus, ${ }^{63}$ and Psamathe is also the name of a spring. ${ }^{64}$

- According to a tradition which we find as early as Pindar, Psamathe bore Phocus on the beach (Pind. N. 5.13).

- The Delphians are „the people of Delphi“, and one is tempted to go further in suggesting that they are the „people of Delphis“, that means, „the people of the seal“". ${ }^{65}$ In the Homeric Hymn to Apollo, the god is transported to Delphi by a dolphin (v. 494).

- Naubolus, son of Ornytion who is in turn son of Phocus, is homonymous with the Phaeacian figure responsible for the dismissal of the ships (Hom. Od. $8.116){ }^{66}$

The areas of interaction of the heroes called Phocus confirm these assumptions, too. The Aeginetan as well as the Corinthian Phocus are active - directly or through their successors - on this and on the other side of the Parnassus. Indeed, the Aeginetan Phocus on the one hand had two sons, Panopeus and Crisus (cat. $58 \mathrm{M}-\mathrm{W}$ ), who were twins but fought each other even in the womb: kinship and enmity are two different but complementary motives, by which union but also defection can be expressed. ${ }^{67}$ On the other hand, the Corinthian Phocus came from the region „around Delphi and Tithorea“ (Paus. 10.1.1), i. e. on this and the other side of the Parnassus, and helped Hyampolis (schol. Hom. 2.517 b); he died in Daphnous (Paus. 10.4.10), whereas Schedius, descendant of Phocus, was buried in Anticyra (10.36.10). The two heroes called Phocus were active on the eastern as well as the western side of Phocis. These traditions show claims of union, which are then also reflected in the traditions about the so-called „First Sacred War" - this is, however, another matter. ${ }^{68}$

62 See Weniger (1902-1909) and Eitrem (1941).

63 Myth. Hom. 4096 fr. 1 Schubert, who cites Theopompus; see also Apoll. Rhod. 3, 158; schol. Eur. Andr. 687. Cfr. with Pind. N. 5.13; see also Radermacher (1904); Kern (1907) 82-87; Zunker (1988) 84; Biagetti (2012) 28.

64 Nic. ther. 887; Plin. nat. 4.7.12.27: Eitrem (1941).

65 McInerney (1999) $136 \mathrm{ff}$.

66 Di Gioia (2012) 3.

67 See mainly Weniger (1902-1909).

68 See Franchi (2016). 


\section{Conclusions}

The survey carried out shows that it is advisable to interpret all the figures named „Phocus“ as different heroes who were more than once linked together to express specific needs. These needs reflect different aims and historical events which are ascribable mainly to the archaic and classical periods. This is the reason why their different genealogies sometimes intertwine before separating out again.

The predominant semantizations working in these links regard Phocians, Locrians, Thebans, Thessalians, Corinthians and Aeginetans. By reconstructing the historical context of these links, the historian can reconstruct a map of cultural and political relationships of the Phocians in the archaic and classical periods. This map emerges from some conclusions we can draw at this point in our survey:

First of all it was noted above that the iconographical sources attest many heroes whose name is Phocus living in different times, including Homeric heroes (see above, p. 4 and n. 24).

Secondly, some traditions attest a Phocus coming from Corinth (point 1 on the map) and often underline the relationships of this Phocus with Tithorea and Hyampolis (possibly starting from the end of the $5^{\text {th }}$ century; see points 2 and 3 on the map) to the point of presuming to claim that he synoikised the Phocians (see above, par. 1).

Thirdly, the stories about the Corinthian Phocus were developed in order to underline the enmity between Phocians and Thebans (point 4 on the map) through the troubled love story between Phocus and the Princess of Thebes, Antiope (see above, par. 1).

Fourthly, there are traditions that attest a Phocus coming from Aegina (starting at the latest from the $6^{\text {th }}$ century - see point 5 on the map), and his murder by Peleus is developed in order to express the enmity of the Phocians towards the Locrians (point 6 on the map), as the story of Peleus wandering through the contested boundary between Phocis and Locris proves (see above, par. 2).

Fifthly, these traditions are likely to be originally Phocian, and were later taken up by the Aeginetans in order to claim affiliations to Delphi (point 7 on the map), to be then elaborated and used in a panhellenic way (possibly starting from the $5^{\text {th }}$ century). Indeed, the Nekya of the Lesche of the Cnidians of Polignotus described by Pausanias seems to suggest that the link of the Aeginetan Phocus to Phocis - the friendship of Phocus with Iaseus! - actually goes back to the first half of the $5^{\text {th }}$ century (see above, par. 2).

Sixthly, it is possible to argue that the connection of a hero named Phocus with Corinth becomes relevant mainly in the $4^{\text {th }}$ century, as results from different 
considerations concerning: a) the first time he appeared: in Ephorus, who presumably is the source of Pseudo-Scymnus; b) the belief, ascribable not only to the archaic period (iconographical sources) but also to the classical, that there exist other heroes whose name was Phocus, as is attested by the scholium A at Hom Il. 2.517; c) a comparative analysis of the genealogies of the Corinthian Phocus on the one hand and of the Aeginetan Phocus on the other, which indicates that the „Corinthian“ genealogy is very likely to have been composed only late and linked in a clumsy way with that of the Aeginetan Phocus; d) the oracle of Bacis citing the Corinthian Phocus which is referred to by Pausanias but goes back to the $4^{\text {th }}$ century; e) the chronological context of the invention of the marriage between Phocus and Antiope, which must be later than the episodes of Antiope's wanderings and Dirce's persecution that in turn seem to date back at the earliest to the end of the $5^{\text {th }}$ century; f) the relationships which existed between the Phocians, Corinthians, Thebans and Locrians: these relationships become relevant chiefly during the Corinthian War, in 395 BC. At this time there existed two groups in Corinth: one was oligarchic and pro-Spartan; the other „democratic“ and antiSpartan. The Phocians were allied with Sparta and were supported by Sparta against Thebes.

Therefore, some stories concerning a Phocus whose homeland was Corinth are very likely to have been invented at this point (see above, par. 3 and 4).

Seventhly, it seems clear that the genealogies of both the Corinthian and the Aeginetan Phocus hint at ties with Thessaly in order to express the relations to the Thessalians (point 8 on the map). This raises the possibility that the dynamic change of the genealogies in a Thessalian mode reflects an intentional rearrangement by which the Phocians claimed to originate from a northern region and therefore to be homoioi with the Thessalians (see above, par. 5).

Eighthly, some traditions about both the Corinthian and the Aeginetan Phocus which show that they were active in the eastern as well as the western side of Phocis seem to reflect underlying and persistent claims of union (see above, par. 6).

To sum up, it seems quite clear at this point that the genealogies of the heroes whose name is Phocus were fluid and multilayered, sometimes even intertwining. They are concerned (as far we know) with Phocis as well as with Corinth, Aegina, Locris, Thebes and Thessaly. By reconstructing wherever possible the chronological context of the different layers and overlaps and by linking them to the several traditions concerning heroes named Phocus, the historian can construct a map which describes some of the relationships, some geopolitical landscapes and, to a certain extent, even some geopolitical lines working in Central Greece and beyond from the archaic to the Roman period. Such a map could explain some alleged contradictions in the stories about the eponymous hero of the Phocians and, what's more, perhaps even help to fill some gaps resulting from 
other sources concerning the same topics, particularly with regard to fourth century Central Greece.

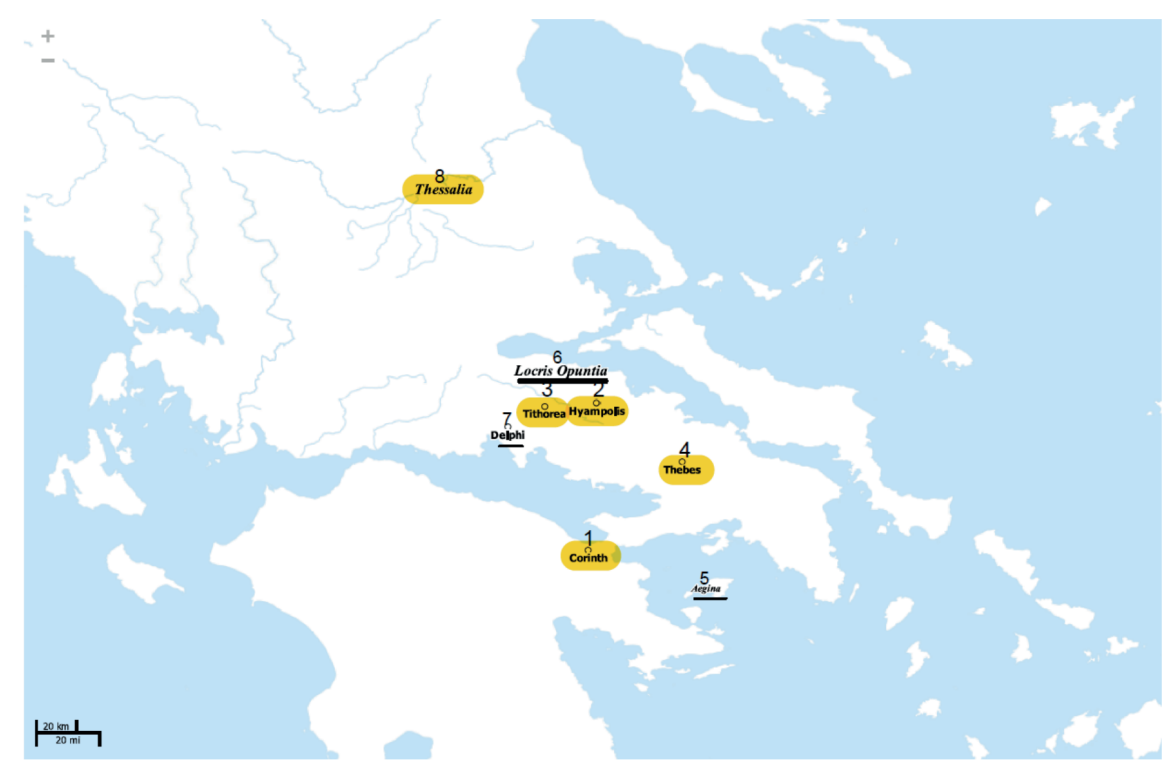

Figure 3

Acknowledgment: This article was written during a period of postdoctoral research funded by the Alexander von Humboldt-Stiftung. I am extremely grateful to Prof. Dr. H.-J. Gehrke, my supervisor, and Prof. Maurizio Giangiulio, the supervisor of my MA thesis and of my PhD thesis. I also express my gratitude to Veronica Bucciantini and Bernd Steinbock for their precious remarks and to Gertraud Wiesthaler and Lilah Grace Canevaro for the English revision. I am responsible for every remaining error.

\section{Bibliography}

Asheri (1993): D. Asheri, Erodoto e Bacide: considerazioni sulla fede di Erodoto negli oracoli (Hdt.

8, 77), in: M. Sordi, La profezia nel mondo antico, Milano 1993, 63-76.

Bates (1907): W. N. Bates, A Tyrrhenian amphora in Philadelphia, AJA 11, 4, 1907, 429-440.

Beck (1997): H. Beck, Polis und Koinon. Untersuchungen zur Geschichte und Struktur der

griechischen Bundesstaaten im 4. Jahrhundert v. Chr, Stuttgart 1997.

Bérard (1983): C. Bérard, Iconographie-Iconologie-Iconologique, EL 4, 1983, 1-37. 
Biagetti (2012): C. Biagetti, Note minime al frammento di Teopompo in POxy LXI 4096, SEP 9, 2012, 27-34.

Bona (1988): G. Bona, Pindaro, I Peani. Testo, traduzione, scoli e commento, Cuneo 1988.

Bravo (2009): B. Bravo, La Chronique d'Apollodore et le Pseudo-Skymnos: érudition antiquaire et littérature géographique dans la seconde moitié du lle siècle av. J.-C., Leuven 2009.

Brunn (1860): H. Brunn, Vaso e scarabeo etrusco, BullInstCorrArch 1860, 233-235.

Buck (1994): R. J. Buck, A History of Boeotia and the Boeotian League, 432-371, Edmonton 1994. Burkert (1985): W. Burkert, Greek Religion. Archaic and Classical, Oxford 1985.

Burnett (2005): A. P. Burnett, Pindar's Song for Young Athletes of Aigina, Oxford 2005.

Burn - Glynn (1982): L. Burn - R. Glynn, Beazley Addenda, Additional References to ABV, ARV \& Paralipomena, Oxford 1982.

Busolt (1908): G. Busolt, Der neue Historiker und Xenophon, Hermes 43, 1908, 255-285.

Camporeale (1965): G. Camporeale, s. v. Puce, in: EAA 6, 1965, 589.

Caprino (1960): C. Caprino, s. v. Giacinto, in: EAA III, 1960, 869-870.

Cartledge (1987): P. Cartledge, Agesilaos and the Crisis of Sparta, London 1987.

Cassola (1980): F. Cassola, Note sulla guerra crisea, in: Philias charin. Miscellanea di studi classici in onore di E. Manni, Rome 1980, 415-439.

Cloché (1952): P. Cloché, Thèbes de Béotie des origines à la conquête romaine, Namur 1952.

Cousin (2000): C. Cousin, Composition, espace et paysage dans les peintures de Polygnote à la leschè de Delphes, Gaia 4, 2000, 61-103.

Cristofani (1983): M. Cristofani, Anello con scarabeo (269), in: M. Cristofani - M. Martelli, L'oro degli Etruschi, Novara 1983, 316-317.

Daverio Rocchi (1988): G. Daverio Rocchi, Frontiera e confini nella Grecia antica, Rome 1988.

Daverio Rocchi (1993): G. Daverio Rocchi, Insediamento coloniale e presidio militare alla frontiera focese-beotica, Tyche 8, 1-8.

Daverio Rocchi (1994): G. Daverio Rocchi, Strutture urbane e centralismo politico nel „koinon“ focese, in: L. Aigner Foresti et al. (eds.), Federazioni e federalismo nell'Europa antica (1994), Atti del Primo Congresso internazionale, Federazioni e federalismo nell'Europa antica, Bergamo 21-25 settembre 1992, Milano 1994, 181-193.

Daverio Rocchi (1999): G. Daverio Rocchi, Identità etnica, appartenenza territoriale e unità politica del koinón focese, OTerr 5, 1999, 15-30.

Daverio Rocchi (2011): G. Daverio Rocchi, Frontiere del Parnasso. Identità etnica e dinamiche locali nella Focide antica, Torino 2011.

Davies (1994): J. Davies, The Tradition about the First Sacred War, in: S. Hornblower (ed.), Greek Historiography, Oxford 1994, 193-212.

De Simone (1968): C. De Simone, Die griechischen Entlehnungen im Etruskischen, Wiesbaden 1968.

Dickey (2007): E. Dickey, Ancient Greek Scholarship, Oxford 2007.

Di Gioia (2012): A. Di Gioia, La duplicità di Phokos e l'identità dei Focidesi, in: L. Breglia - A. Moleti - M. L. Napolitano, Ethne, identità e tradizioni: la „terza“ Grecia e l’Occidente, Pisa 2012, 197-218.

Eitrem (1941): S. Eitrem, s. v. Phokos (3), in: RE XX.1, 1941, 497-502.

Ellinger (1993): P. Ellinger, La légende nationale phocidienne. Les situations extrêmes et les récits de guerre d'anéantissement, Athens 1993.

Enking (1959): R. Enking, s. v. Puce, in: RE XXIII.2, 1959, 1937-1938.

Fontenrose (1978): J. Fontenrose, The Delphic Oracle. Its Responses and Operations, Berkeley 1978. 
Forrest (1956): G. Forrest, The First Sacred War, BCH 80, 1956, 33-52.

Franchi (2013): E. Franchi, Die Herkunft der Phlegyer und der dritte Heilige Krieg, Hermes 141, 2013, 450-458.

Franchi (forthc.): E. Franchi, The Memory of the Sacred Wars and Some Origin Stories, in: M. Giangiulio - E. Franchi - G. Proietti (eds.), Commemorating War and War Dead. Ancient and Modern, forthcoming.

Franchi (2016): E. Franchi, Die Konflikte zwischen Thessalern und Phokern. Krieg und Identität in der griechischen Erinnerungskultur des 4. Jhs. (Quellen und Forschungen zur antiken Welt), München 2016, chapt. 5 .

French (1984): E. French, New Finds at the Phokikon, in: Studies Presented to S. Dow (Greek, Roman and Byzantine Monographs, X), Durham 1984, 89-96.

French - Vanderpool (1963): E. French - E. Vanderpool, The Phokikon, Hesperia 23, 1963, 213-225.

Froning (1981): H. Froning, Marmor-Schmuckreliefs mit griechischen Mythen im 1. Jh. v. Chr., Mainz 1981.

Funke (1980): P. Funke, Homonoia und Arche. Athen und die Griechische Staatenwelt vom Ende des Peloponnesischen Krieges bis zum Königsfrieden (404/3-387/6 v. Chr.), Wiesbaden 1980.

Furtwängler (1900): A. Furtwängler, Die antiken Gemmen, Leipzig 1900.

Gantz (1993): T. Gantz, Early Greek Myth. A Guide to Literary and Artistic Sources, Baltimore London 1993.

Gehrke (1985): H. J. Gehrke, Stasis. Untersuchungen zu den inneren Kriegen in den griechischen Staaten des 5. und 4. Jh. v. Chr., München 1985.

Gibert (2009): J. Gibert, Euripides' Antiope an the Quiet Life, in: J.R.C. Cousland - J. R. Hume, The Play of Texts and Fragments. Essay in Honour of Martin Cropp, Leiden 2009, 23-34.

Greifenwagen (1977): A. Greifenwagen, Bronzenes Stierkopfrhyton Berlin 30492, in: L. Grisebach K. Renger, Festschrift für Otto von Simson zum 65. Geburtstag, Frankfurt a. M. 1977, 19-26.

Gudeman (1921): A. Gudeman, s. v. Scholien, in: RE II.1, 1921, 625-705.

Heidenreich (1951): M. Heidenreich, Zu den frühen Troilosbildern, MdI 116, 1951, 103-119.

Hoffmann (1966): H. Hoffmann, Tarentine Rhyta, Berlin 1966.

Immerwahr (1998): H. R. Immerwahr, A Corpus of Attic Vase Inscriptions, Oxford 1998.

Jahn (1853): O. Jahn, Antiope und Dirke, AZ 11, 1853, 56, 66-112.

Kebric (1983): R. B. Kebric, The Paintings in the Cnidian Lesche at Delphi and Their Historical Context, Leiden 1983.

Kern (1907): 0. Kern, Der Robbengott Phokos, ARW 10, 1907, 82-87.

Korenjak (2012): M. Korenjak, [Skymnos] (2048), in: H.-J. Gehrke, Die Fragmente der Griechischen Historiker Part V, Brill Online, 2012 <http://referenceworks.brillonline.com/ entries/fragmente-der-griechischen-historiker-v/skymnos-2048-a2048.

Kossatz-Deissmann (1992): A. Kossatz-Deissmann, s. v. Lyssa, in: LIMC VI, 1992, 322-329.

Kowalzig (2007): B. Kowalzig, Singing for the Gods. Performances of Myth and Ritual in Archaic and Classical Greece, Oxford 2007.

Kühr (2006): A. Kühr, Als Kadmos nach Boiotien kam. Polis und Ethnos im Spiegel thebanischer Gründungsmythen, Stuttgart 2006.

Kurtz (1971): D. C. Kurtz (ed.), Paralipomena. Additions to Attic Black-Figure Vase-Painters and to Attic Red-Figure Vase-Painters, Oxford 1971.

Larsen (1968): J.A.O. Larsen, Greek Federal States. Their Institutions and History, Oxford 1968. Lehmann (1983): G. A. Lehmann, Thessaliens Hegemonie über Mittelgriechenland im 6. Jh. v. Chr., Boreas 6, 1983, 35-43. 
Lendon (1989): J. E. Lendon, The Oxyrhynchus Historian and the Origins of the Corinthian War,

Historia 38, 1989, 300-313.

Leitao (2003): D. D. Leitao, Adolescent Hair-Growing and Hair-Cutting Rituals in Ancient Greece. A

Sociological Approach, in: C. Faraone - D. B. Dodds, Initiation in Ancient Greek Rituals and

Narratives. New Critical Perspectives, London - New York 2003, 109-129.

Lesky (1937): A. Lesky, s. v. Peleus, in: RE XIX 1, 1937, 271-308.

Malkin (2001): I. Malkin (ed.), Ancient Perceptions of Greek Ethnicity. Center for Hellenic Studies

Colloquia, Cambridge (MA) ${ }^{5} 2001$.

Mannack (2001): T. Mannack, The Late Mannerists in Athenian Vase-Painting, Oxford 2001.

Manoledakis (2003): M. Manoledakis, Nekyia: Hermēneutikē Prosengisē tēs Synthesēs tou

Polygnōtou stē „Leschē tōn Knidiōn“ stous Delphous, Thessaloniki 2003.

Marcotte (2000): D. Marcotte, Géographes grecs, I, Introduction générale. Ps.- Scymnos: Circuit de la Terre, Paris 2000.

Marshall (1907): F. H. Marshall, Catalogue of the Finger Rings, Greek, Etruscan and Roman in the

Departments of Antiquities, British Museum, London 1907.

Masner (1907): K. Masner, Sammlung antiker Vasen und Terrakotten, Wien 1892.

McInerney (1997): J. McInerney, The Phokikon and the Hero Archegetes, Hesperia 66.2, 1997, 193-207.

McInerney (1999): J. McInerney, The Folds of Parnassos: Land and Ethnicity in Ancient Phokis, Austin 1999.

Meyer (1909): Ed. Meyer, Theopomps Hellenika, Halle 1909.

O’Neill (1930): J.G. O’Neill, Ancient Corinth, Baltimore 1930.

Panofka (1855): Th. Panofka, Phokos und Antiope, Winckelmanns-Programm der Archäologischen Gesellschaft zu Berlin 1855, 1-13.

Parke - Boardman (1957): H. W. Parke - J. Boardman, The Struggle for the Tripod and the First Sacred War, JHS 77, 1957, 276-282.

Pauli (1902-1907): C. Pauli, s. v. Puci, in: Roscher, Ausführliches Lexikon der griechischen und römischen Mythologie 3.2, 1902-1907, 3272.

Pease (1935): M. Z. Pease, The Pottery from the North Slope of the Acropolis, Hesperia 4.2, 1935, 214-302.

Perlman (1964): S. Perlman, The Causes and the Outbreak of the Corinthian War, CQ n.s. 14, 1964, 64-81.

Polinskaya (2013): I. Polinskaya, A Local History of Greek Polytheism, Leiden - Boston 2013.

Pouilloux (1960): J. Pouilloux, La région Nord du sanctuaire d'Apollon, Paris 1960.

Prandi (1981): L. Prandi, I Flegiei di Orcomeno e Delfi. La preistoria delle guerre sacre, in: M. Sordi (ed.), Religione e politica nel mondo antico, Milano 1981, 51-63.

Prandi (1993): L. Prandi, Considerazioni su Bacide e le raccolte oracoli greche, in: M. Sordi (ed.), La profezia nel mondo antico, Milan 1993, 51-62.

Prinz (1979): F. Prinz, Gründungsmythen und Sagenchronologie, München 1979.

Radermacher (1904): L. Radermacher, St. Phokas, ARW 7, 1904, 445-452.

Raeck (1984): W. Raeck, Zur Erzählweise archaischer und klassischer Mythenbilder, Jdl 99, 1984, $1-25$.

Robert (1892): C. Robert, Die Nekyia des Polignot, Halle 1892.

Robert - Preller (1854): C. Robert - L. Preller, Griechische Mythologie, 2, Berlin 1854.

Rocchi (1986): M. Rocchi, Le Tombeau d'Amphion et de Zéthos et les Fruits de Dionysos, in:

A. Bonanno, Archaeology and Fertility Cult in the Ancient Mediterranean, Malta 1986, 257266. 
Roebuck (1940): C. Roebuck, Fragments joining vases, Hesperia 2, 1940, 146-149.

Rousset (2002): D. Rousset, Le territoire de Delphes et la terre d'Apollon, Athens 2002.

Rutherford (2001a): I. Rutherford, Tourism and the Sacred: Pausanias and the Traditions of Greek Pilgrimage, in: S. E. Alcock - J. F. Cherry - J. Elsner (eds.), Pausanias. Travel and Memory in Roman Greece, Oxford 2001, 40-51.

Rutherford (2001b): I. Rutherford, Pindar's Paeans. A Reading of the Fragments with a Survey of the Genre, Oxford 2001.

Sánchez (2001): P. Sánchez, L’Amphictionie des Pyles et de Delphes, Stuttgart 2001.

Schachter (1981): A. Schachter, Cults of Boeotia, I, London 1981.

Schefold (1957): K. Schefold, Die Wände Pompeis, Berlin 1957.

Schefold (1964): K. Schefold, Frühgriechische Sagenbilder III, München 1964.

Schober (1924): F. Schober, Phokis, Jena 1924.

Simon (1994): E. Simon, s. v. Antiope, Antiope und Phokos, in: LIMC I.1, 1994, 856-857.

Shapiro (2000): H. A. Shapiro, Helen Out of Doors, in: G. R. Tsetskhladze - A.J.N.W. Prag - A. M. Snodgrass (eds.), Periplous. Papers on Classical Art and Archaeology Presented to Sir John Boardman, London 2000, 271-275.

Smith (1888): C.A.H. Smith, A Catalogue of Engraved Gems in the British Museum, London 1888.

Stähler (1989): K. Stähler, Die Lesche der Knidier - ein Heroon des Neoptolemos?, Boreas 12, 1989, 15-17.

Stansbury-O’Donnell (1990): M. D. Stansbury-O’Donnell, Polygnotos's Nekyia. A Reconstruction and Analysis, AJA 94.2, 1990, 213-235.

Symeonoglou (1985): S. Symeonoglou, The Topography of Thebes from the Bronze Age to Modern Times, Princeton 1985.

Taplin (1998): O. Taplin, Narrative Variation in Vase-Painting and Tragedy, AK 41, 1998, 33-39.

Thomas (2001): R. Thomas, Ethnicity, Genealogy, and Hellenism in Herodotus, in: Malkin (2001) 213-233.

Tuchelt (1962): K. Tuchelt, Tiergefässe in Kopf- und Protomengestalt, Berlin 1962.

Von Bothmer (1977 a): D. Von Bothmer, The Struggle for the tripod, in: U. Höckmann - A. Krug (eds.), Festschrift für F. Brommer, Mainz 1977, 51-63.

Van Bothmer (1977b): D. Von Bothmer, Halsamphora del O.L.L. Gruppe (233), in: W. Hornbostel et al. (eds.), Kunst der Antike. Schätze aus dem Norddeutschem Privatbesitz, Mainz 1977, 251253.

Van Thiel (2000a): H. Van Thiel, Scholia D in Iliadem, http://kups.ub.uni-koeln.de/1810 (last accessed 06.04.2017).

Van Thiel (2000b): H. Van Thiel, Die D-Scholien der Ilias in den Handschriften, ZPE 132, 2000, 1-15. von Wilamowitz (1931): U. von Wilamowitz, Der Glaube der Hellenen, Basel 1931.

Weniger (1902-1909): L. Weniger, s.v. Phokos la, in: Roscher, Ausführliches Lexikon der griechischen und römischen Mythologie, 1902-1909, 2410-2412.

Wernicke (1894): K. Wernicke, s. v. Antiope (1), in: RE I, 1894, 2495-2497.

West (1983): M. L. West, The Hesiodic Catalogue: Xouthids and Aiolids, ZPE 53, 1983, 27-30.

West (1985): M. L. West, The Hesiodic Catalogue of Women, Oxford 1985.

Will (1955): E. Will, Korinthiaka, Paris 1955.

Zindel (1974): Ch. Zindel, Drei vorhomerische Sagenversionen in der griechischen Kunst, Basel 1974.

Zunker (1988): A. Zunker, Untersuchungen zur Aiakidensage auf Aigina, St. Ottilien 1988. 